\title{
Short communication: Jenny milk production and qualitative characteristics
}

\author{
C. Cosentino, ${ }^{1}$ R. Paolino, P. Freschi, and A. M. Calluso \\ Dipartimento di Scienze delle Produzioni Animali-Facoltà di Agraria-Università degli Studi della Basilicata, Viale dell'Ateneo Lucano 10, \\ 85100 Potenza, Italy
}

\begin{abstract}
The aim of this research was to study the influence of lactation stage and foaling season on some qualitative aspects of milk in South Italian jenny rearing. Milk samples were collected monthly from 23 jennies, that foaled in 2 different periods: spring and summer. On milk, the following parameters were measured: $\mathrm{pH}$ and titratable acidity; protein, fat, lactose, dry matter, and ash contents; and somatic cell count. Analysis of variance showed the effect of foaling season and lactation stage. Milk production was highest in summer at 30 $\mathrm{d}$ and at $60 \mathrm{~d}$ (1.58 and $1.78 \mathrm{~L}$, respectively), and in spring at $120 \mathrm{~d}(1.25 \mathrm{~L})$. The total protein content was highest in summer lactation at $30 \mathrm{~d}$ and $90 \mathrm{~d}$ (14.8 and $13.9 \mathrm{~g} / \mathrm{L})$. Lactose, dry matter, and ash contents (g/L) were highest in summer lactation at $30 \mathrm{~d}$ (54.0, 78.1, and 5.0 respectively). Jenny milk was shown to be poor in protein and fat and rich in lactose. Producing jenny milk could be an interesting, profitable, and alternative activity for farmers, mainly in southern marginal areas. Key words: jenny milk, lactation, chemical composition, foaling season
\end{abstract}

\section{Short Communication}

Among species reared for milk production, jennies furnish a milk that shows the closest similarity to human milk. Today, jenny milk is difficult to find because donkey breeding is not widespread. Jenny milk has recently stimulated scientific interest for its attractive nutritional characteristics that make it fit to use in the pediatric sphere, in patients affected by cow milk protein allergies (CMA) and intolerance, as the best alternative to human milk in infant food, and in the geriatric field for the treatment of aging diseases. In particular, CMA occur predominantly in childhood and represent the most common allergy in infants. Any potential allergens of cow milk that can cause allergic reactions in

Received December 6, 2011.

Accepted January 29, 2012.

${ }^{1}$ Corresponding author: carlo.cosentino@unibas.it the immune-mediated gut of the newborn are caseins and whey proteins (El-Agamy, 2007; El-Agamy et al., 2009; Tesse et al., 2009; Caffarelli et al., 2010). The total protein content is present in very low amounts in jenny milk; in particular, it shows a lower ratio casein/whey protein (Herrouin et al., 2000; Vincenzetti et al., 2008; Restani et al., 2009). This milk has low levels of casein, and high levels of lactose, unsaturated FA (linoleic and linolenic), and lysozyme. This enzyme is practically absent in other species (cow, goat, sheep, and human; Miranda et al., 2004; Vincenzetti et al., 2008) and has important physiological functions, such as inhibition of growth of certain microorganisms; antiinflammatory and antitumoral activity; increase in defense system in early childhood (Monti et al., 2007; Zhang et al., 2008; La Torre et al., 2010; Nazzaro et al., 2010; Simos et al., 2011). Some jenny milk whey proteins ( $\alpha$-LA in particular, and $\beta$-LG) stimulate cytokine production with considerable in vitro antiproliferative activity (Girardet et al., 2004; Erdmann et al., 2008; Criscione et al., 2009; Mao et al., 2009). Moreover, thanks to some of its characteristics (vasodilator function, high calcium content, and low energy value) it is indicated in patients affected by heart disease, osteoporosis, and atherosclerosis (Hernández-Ledesma et al., 2006; Iacono and Scalici, 2011). In cosmetics, it is often used as basic constituent. Minerals, vitamins, FA, bioactive enzymes and coenzymes, lactose, and whey proteins contained in jenny milk prevent skin aging processes and hydrating and restructuring action of the dermal intercellular substance (Cosentino et al., 2011; Orsingher, 2011).

Little is known about qualitative and quantitative characteristics of jenny milk. During lactation, this species has a low but constant daily production (Malacarne et al., 2002; Polidori et al., 2009). Production level is related in prevalence to the milking technique, to the presence of the foal, to the foaling season, and to the stage of lactation (Oftedal et al., 1983; Aguggini et al., 1992; Dell'Orto et al., 1993). During milking, the principal factors that influence fat and protein content are the presence of foal and the stage of lactation. Lactose content is constant during lactation and is independent of breed, milking time, and stage of lactation (Guo et al., 2007). Studies on jenny milk from different con- 


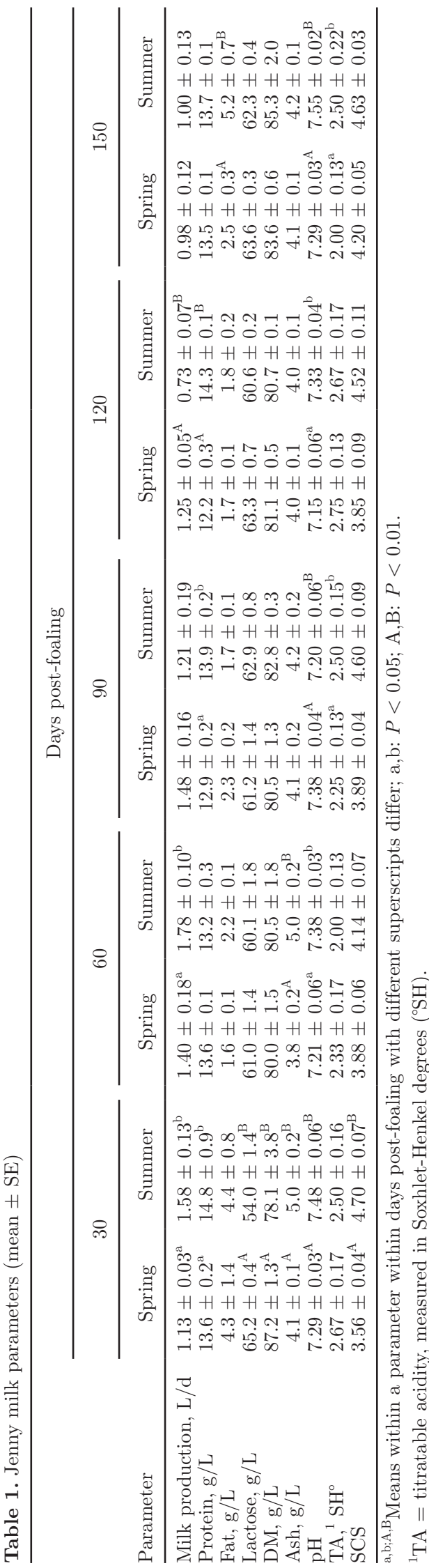

tinents showed a close similarity in its composition, except for fat content (Blasi et al., 2008; Ivanković et al., 2009). The donkey is a seasonal polyestrous species. Nevertheless, South Italian jennies foal every season, probably because of small photoperiod oscillations between different seasons and, consequently, milk is available all year (Giosuè et al., 2008). The aim of this research was to study the influence of lactation stage and of foaling season on some qualitative aspects of jenny milk in rearing situated in the Basilicata region (southern Italy).

The research was carried out on 23 jennies that foaled in 2 different periods: spring and summer (11 and 12 jennies, respectively). Jennies, belonging to a local population, aged between 7 and $10 \mathrm{yr}$, were reared in a farm situated at an altitude of $700 \mathrm{~m}$ above sea level. During the trial, jennies and foals did not show detectable behavioral and health problems. Milk produced in the first month of lactation was fully intended for the foal. Milk samples were collected monthly, starting from the second post-foaling month, in the periods March to August in the spring group, and July to November in the summer group. During the trial period, jennies were confined in stalls with a large paddock, to avoid the effect of grazing on qualitative characteristics of milk. Animals were offered a diet consisting of ad libitum oat hay and an integration of $3 \mathrm{~kg}$ of concentrate, characterized by the following mixture: $37 \%$ flaked corn, $30 \%$ oats, 9\% locust bean (crushed), $8 \%$ wheat bran, $8 \%$ dehydrated alfalfa, $6 \%$ beet pulp (dried), and $2 \%$ mineral and vitamin supplement. The diet was dispensed twice per day: during milking and in the evening. From the second month after delivery, jennies were milked by mechanical milking ( $40 \mathrm{kPa}$ vacuum level, 60 pulses per min), at $1100 \mathrm{~h}$. From $0800 \mathrm{~h}$ to the end of milking, foals were separated from mares, but were kept in the adjacent stall, maintaining visual and acoustic contact. Milk individual samples were collected for analysis, and were refrigerated at $4^{\circ} \mathrm{C}$.

Immediately after collection, the $\mathrm{pH}$ (MeterLab PHM 240; Radiometer Analytical SAS, Lyon, France) and titratable acidity [TA; by Soxhlet-Henkel $\left({ }^{\circ} \mathrm{SH}\right)$ direct method] were measured. Two hours after collection, protein, fat, and lactose concentrations were measured on raw milk using a MilkoScan FT 6000 (Foss Electric A/S, Hillerød, Denmark). Dry matter and ash content were measured using methods of the Association of Official Analytical Chemists (AOAC, 1990). In addition, SCC, expressed as SCS $\left(\log _{10} \mathrm{n} \times 1,000 / \mathrm{mL}\right)$, was determined using a Fossomatic 5000 (Foss Electric $\mathrm{A} / \mathrm{S})$.

Data obtained were statistically analyzed by the GLM procedure (SAS Institute, 2001) using a linear model that included the foaling season (spring and 


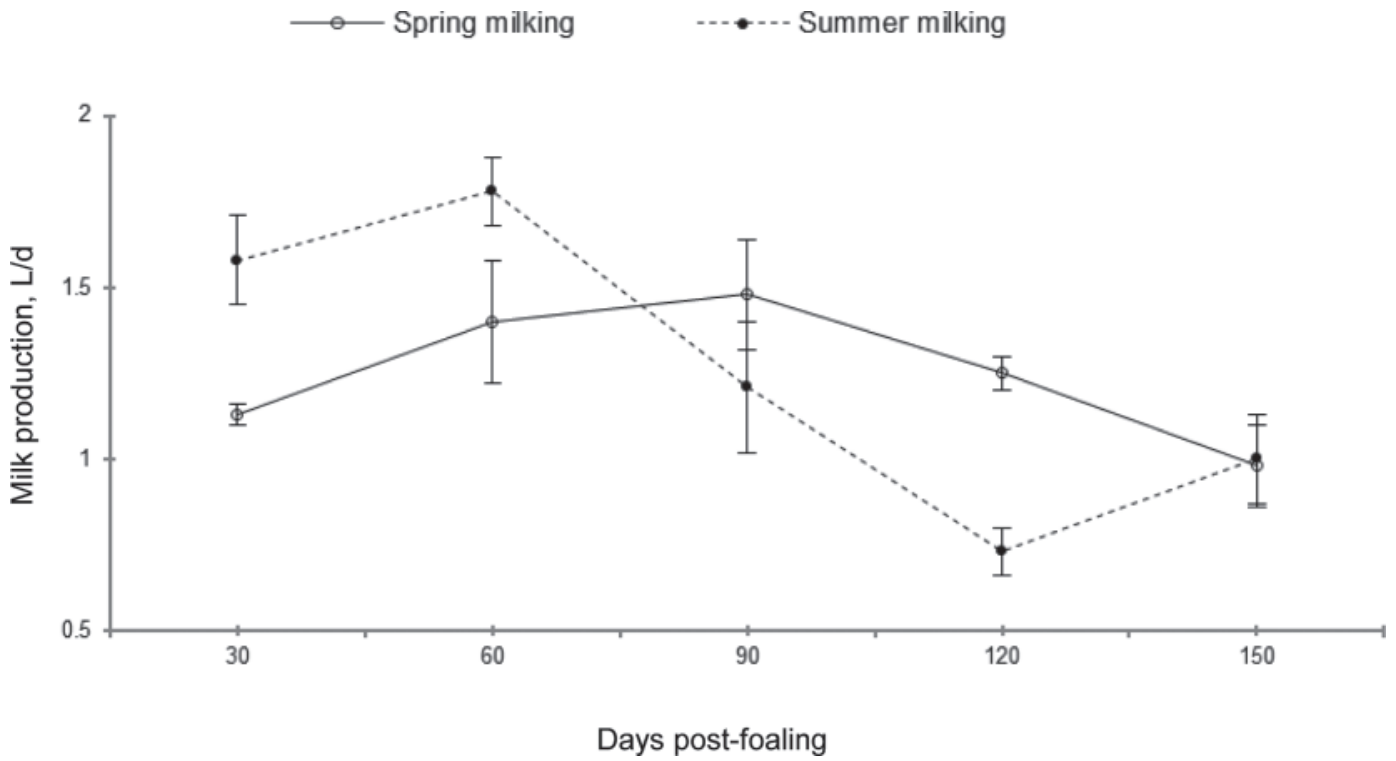

Figure 1. Milk production in jennies.

summer) and the lactation stage $(30,60,90,120$, and $150 \mathrm{~d}$ from foaling) as factors. Differences between means were tested by the Student's $t$-test. Interaction (foaling season $\times$ lactation stage) was eliminated from the model because it was not significant.

Analysis of variance showed the effect of foaling season and of lactation stage. Milk production parameters are reported in Table 1 and in Figures 1 to 4 . Milk production $(\mathrm{L} / \mathrm{d})$ was highest in the summer $(P<0.05)$ at $30 \mathrm{~d}(1.58$ vs. 1.13$)$ and at $60 \mathrm{~d}(1.78$ vs. 1.43$)$, and in the spring $(P<0.01)$ at $120 \mathrm{~d}(1.25$ vs. 0.73$)$. The lactation curve presented 2 peaks: at 60 and $150 \mathrm{~d}$ in the summer group and a peak at $90 \mathrm{~d}$ in the spring group. The milk production trend was similar to that observed

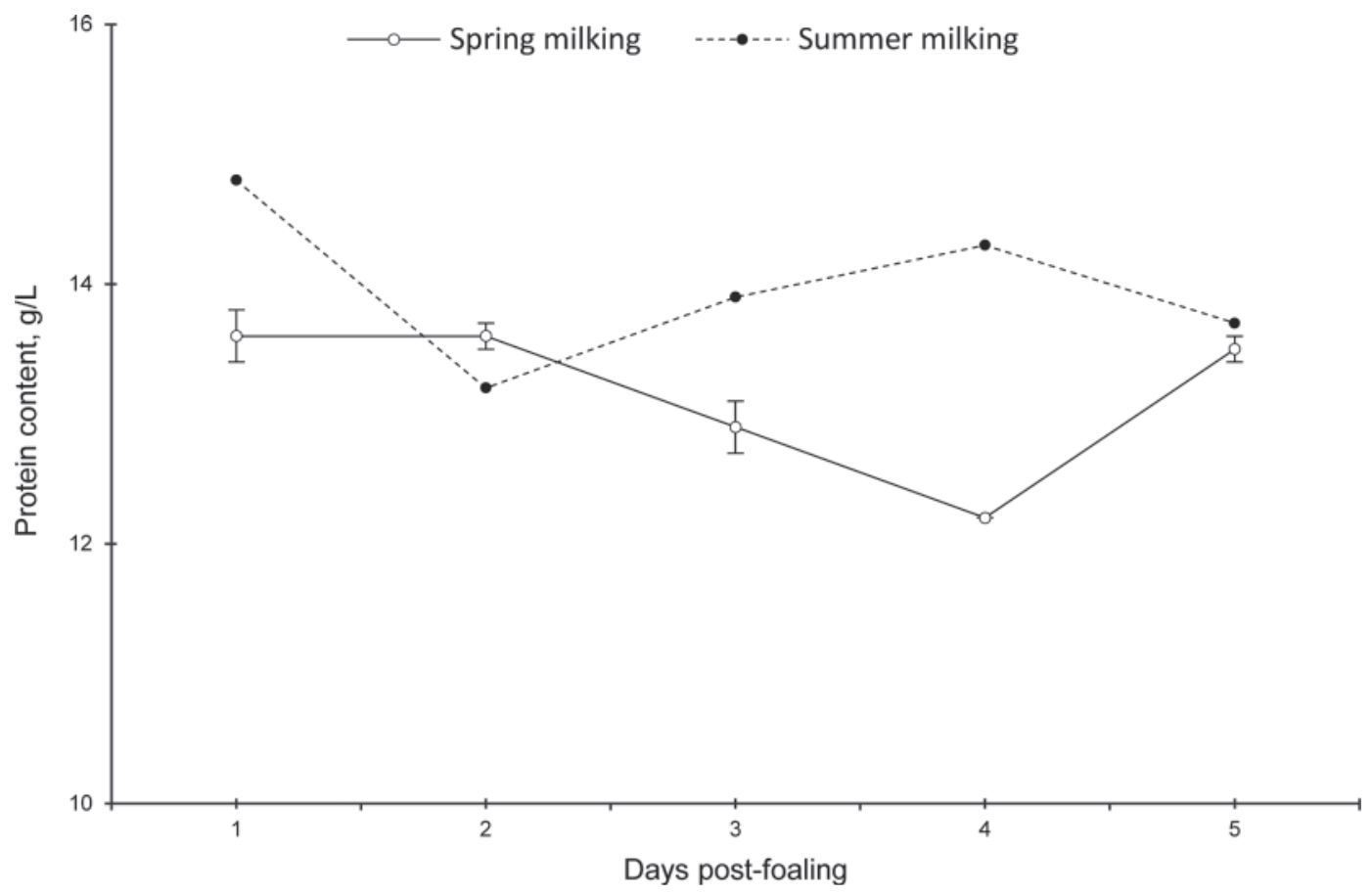

Figure 2. Protein content in jenny milk. 


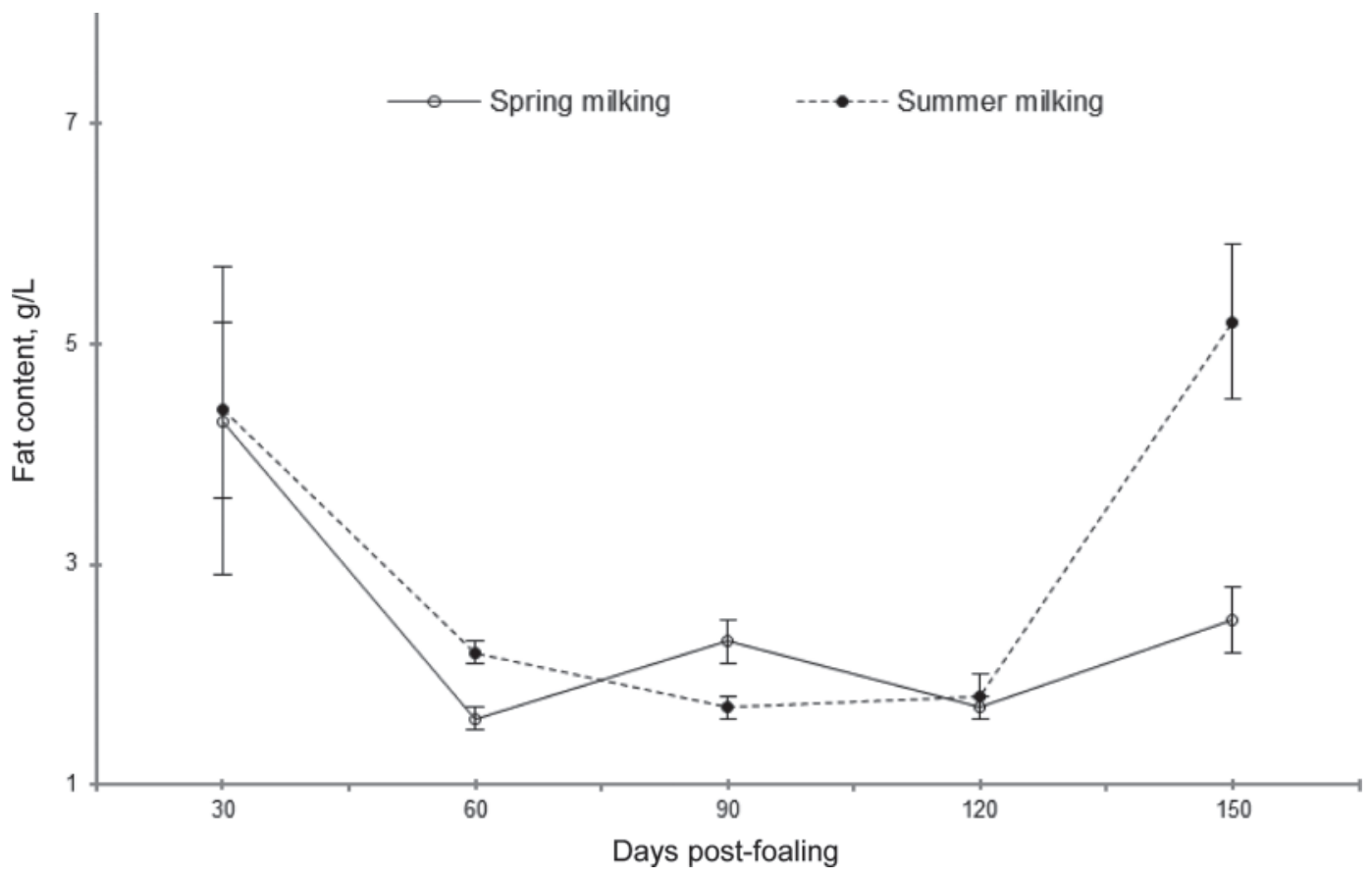

Figure 3. Fat content in jenny milk.

in the literature by other authors (Giosuè et al., 2008; Piccione et al., 2008; Santos and Silvestre, 2008). The total protein content $(\mathrm{g} / \mathrm{L})$ was significantly highest $(P$
$<0.05)$ in the summer lactation at $30 \mathrm{~d}$ (14.8 vs. 13.6) and at $90 \mathrm{~d}$ (13.9 vs. 12.9). In the spring group, protein content was high at the start of lactation, decreased

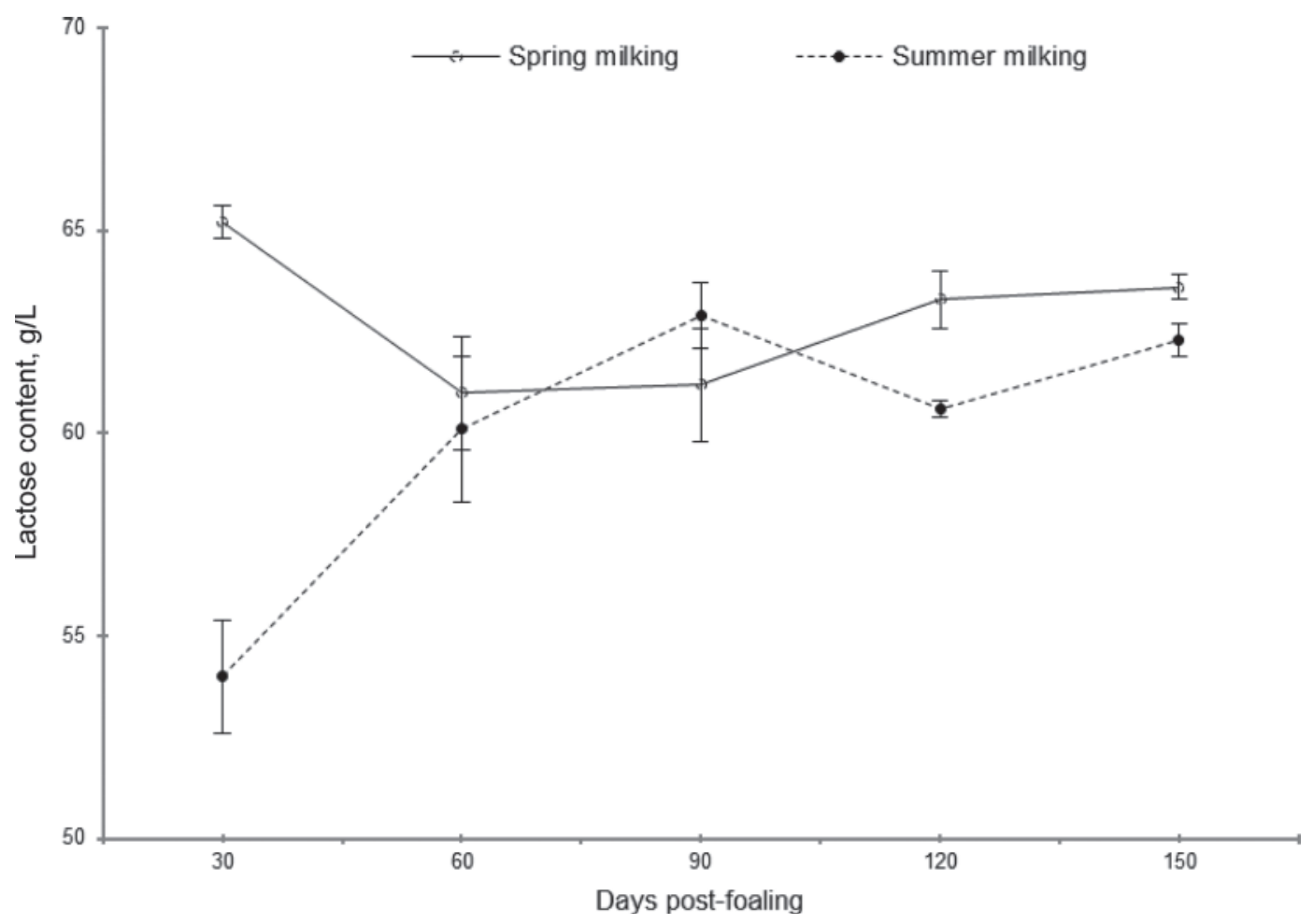

Figure 4. Lactose content in jenny milk. 
to a minimum at $120 \mathrm{~d}$, and increased at the end of lactation, as observed by Guo et al. (2007); instead, summer lactation showed 2 peaks at 30 and at $120 \mathrm{~d}$. The protein content was lower than the values reported by other authors who studied the effects of seasons on jennet milk characteristics: $19.3 \mathrm{~g} / \mathrm{L}$ in the spring and $18.1 \mathrm{~g} / \mathrm{L}$ in the summer in Sicilian breeds (Giosuè et al., 2008); $16.5 \mathrm{~g} / \mathrm{L}$ in the spring and $14.3 \mathrm{~g} / \mathrm{L}$ in the summer in Croatian breeds (Ivanković et al., 2009).

Fat content $(\mathrm{g} / \mathrm{L})$ was significantly highest in the summer $(P<0.01)$ at $150 \mathrm{~d}(5.2$ vs. 2.5$)$. The average fat content of jenny milk was similar to mare milk and was much lower than in other mammals; other authors observed values (in percent) in the range of 0.01 to 1.8 (Giosuè et al., 2008; Ivanković et al., 2009).

Lactose content $(\mathrm{g} / \mathrm{L})$ was significantly lowest $(P<$ $0.01)$ in the summer only at $30 \mathrm{~d}$ (54.0 vs. 65.2$)$. In the other periods, lactose was not influenced by the considered factors, as reported in the literature (Oftedal and Jenness, 1988; Santos and Silvestre, 2008).

Dry matter content $(\mathrm{g} / \mathrm{L})$ was lowest in the summer $(P<0.001)$ at $30 \mathrm{~d}(78.1$ vs. 87.2$)$, in agreement with values reported in the literature for equine milk (Malacarne et al., 2002; Miranda et al., 2004). Ivanković et al. (2009) observed in Croatian jennets values that ranged from 8.61 to $9.13 \%$.

Ash content $(\mathrm{g} / \mathrm{L})$ was highest $(P<0.01)$ in the summer lactation at $30 \mathrm{~d}(5.0 \mathrm{vs} .4 .1)$ and at $60 \mathrm{~d}(5.0$ vs. 3.8). The highest mineral content at the start of lactation is particularly important for the first growth stage of the young foal (Csapó-Kiss et al., 1995).

During lactation, $\mathrm{pH}$ values varied significantly between groups. The spring group presented the highest value $(P<0.01)$ at $90 \mathrm{~d}(7.38$ vs. 7.20$)$. The TA $\left(\mathrm{SH}^{\circ}\right)$ was highest $(P<0.05)$ in the summer lactation at 90 d (2.50 vs. 2.25$)$ and at $150 \mathrm{~d}$ (2.50 vs. 2.00). The TA of jenny milk (lower than in cow's milk), is attributable to the low content of casein and phosphate (D'Auria et al., 2005; Guo et al., 2007).

The SCS was significantly highest $(P<0.01)$ in the summer lactation at $30 \mathrm{~d}$ (4.70 vs. 3.56$)$. Values observed from other authors ranged from 3.94 to 4.34 (Beghelli et al., 2009; Finocchiaro and Conte, 2009; Ivanković et al., 2009).

Considering its unique nutrient profile, jenny milk could be exploited to satisfy the nutritional requirements of newborn, heart, and cholesterolemic patients. In particular, cow milk allergies, heart aging, and cholesterolemic diseases are considered to be increasing problems and, for these reasons, the acquisition of new knowledge on jenny milk is very important in clinical and nutritional aspects. Jenny milk can be considered a natural solution, and the results obtained by pediatric scientists seem to confirm its nutritional value.
In particular, it will play an important role in the improvement of the host defense system in newborns that cannot be nourished by human milk or are allergic to other milk. Producing jenny milk could be an interesting, profitable, and alternative activity for farmers, mainly in marginal areas of Southern Italy.

\section{ACKNOWLEDGMENTS}

This study was supported by Regione BasilicataOnocosmesi Project "Conservation and preservation of the species mule through the exploitation of marginal areas in onocosmesi products from milk of donkeys" (Dipartimento Agricoltura, Sviluppo Rurale ed Economia Montana, Basilicata, Italy; Onocosmesi project).

\section{REFERENCES}

Aguggini, G., V. Beghelli, and L. F. Giulio. 1992. Pages 662-664 in Fisiologia degli Animali Domestici con Elementi di Etologia [Physiology of Domestic Animals and Elements of Ethology]. Utet, Torino, Italy.

AOAC. 1990. Official Methods of Analysis. 15th ed. Association of Official Analytical Chemists Arlington, VA.

Beghelli, D., A. Roscini, A. Valiani, S. Vincenzetti, C. Cavallucci, and P. Polidori. 2009. Somatic (CSS) and differential cell count (DCC) during a lactation period in ass' milk. Ital. J. Anim. Sci. 8:691-693.

Blasi, F., D. Montesano, M. De Angelis, A. Maurizi, F. Ventura, L. Cossignani, M. S. Simonetti, and P. Damiani. 2008. Results of stereospecific analysis of triacylglycerol fraction from donkey, cow, ewe, goat and buffalo milk. J. Food Compost. Anal. 21:1-7.

Caffarelli, C., F. Baldi, B. Bendandi, L. Calzone, M. Marani, and P. Pasquinelli. 2010. Cow's milk protein allergy in children: A practical guide. Ital. J. Pediatr. 36:5.

Cosentino, C., V. Valentini, P. Freschi, and R. Paolino. 2011. Il latte di asina nella cosmesi Indagine conoscitiva tra innovazione e tradizione [Consumer liking and willingness to pay for cosmetics with jenny milk]. Cosmetic Technol. 14:21-24.

Criscione, A., V. Cunsolo, S. Bordonaro, A. M. Guastella, R. Saletti, A. Zuccaro, G. D'Urso, and D. Marletta. 2009. Donkeys' milk protein fraction investigated by electrophoretic methods and mass spectrometric analysis. Int. Dairy J. 19:190-197.

Csapó-Kiss, Z., J. Stefler, T. G. Martin, S. Makray, and J. Csapó. 1995. Composition of mares' colostrum and milk. Protein content, amino acid composition and contents of macro- and micro-elements. Int. Dairy J. 5:403-415.

D'Auria, E., C. Agostoni, M. Giovannini, E. Riva, R. Zetterström, R. Fortin, G. F. Greppi, L. Bonizzi, and P. Roncada. 2005. Proteomic evaluation of milk from different mammalian species as a substitute for breast milk. Acta Paediatr. 94:1708-1713.

Dell'Orto, V., E. Salimei, V. Bontempo, F. Fantuz, P. M. Toppino, and G. Contarini. 1993. Produzione e composizione di latte equino: Osservazioni sperimentali [Production and composition of equine milk: Experimental observation]. Atti S.I.S. Vet. (Kiev) 47:20732077.

El-Agamy, E. I. 2007. The challenge of cow milk protein allergy. Small Rumin. Res. 68:64-72.

El-Agamy, E. I., M. Nawar, S. M. Shamsia, S. Awad, and G. F. W. Haenlein. 2009. Are camel milk proteins convenient to the nutrition of cow milk allergic children? Small Rumin. Res. 82:1-6.

Erdmann, K., B. W. Y. Cheung, and H. Schröder. 2008. The possible roles of food-derived peptides in reducing the risk of cardiovascular disease. J. Nutr. Biochem. 19:643-654. 
Finocchiaro, A., and F. Conte. 2009. La conducibilità elettrica del latte d'asina [Conductivity of donkey milk]. Associazone Italiana Veterinari Igienisti 4:65-66.

Giosuè, C., M. Alabiso, G. Russo, M. L. Alicata, and C. Torrisi. 2008. Jennet milk production during the lactation in a Sicilian farming system. Animal 2:1491-1495.

Girardet, J.-M., M.-A. N'negue, A. S. Egito, S. Campagna, A. Lagrange, and J.-L. Gaillard. 2004. Multiple forms of equine $\alpha$-lactalbumin: Evidence for N-glycosylated and deamidated forms. Int. Dairy J. 14:207-217.

Guo, H. Y., K. Pang, X. Y. Zhang, L. Zhao, S. W. Chen, M. L. Dong, and F. Z. Ren. 2007. Composition, physiochemical properties, nitrogen fraction distribution, and amino acid profile of donkey milk. J. Dairy Sci. 90:1635-1643.

Hernández-Ledesma, B., M. Ramos, I. Recio, and L. Amigo. 2006. Effect of $\beta$-lactoglobulin hydrolysis with thermolysin under denaturing temperatures on the release of bioactive peptides. J. Chromatogr. A 1116:31-37.

Herrouin, M., D. Mollé, J. Fauquant, F. Ballestra, J.-L. Maubois, and J. Léonil. 2000. New genetic variants Identified in donkey's milk whey proteins. J. Protein Chem. 19:105-115.

Iacono, G., and C. Scalici. 2011. Uso del latte di asina come soluzione di problemi pratici [Use of jenny milk as a solution of practical problems]. Pages 259-266 in Latte di asina, produzione, caratteristiche e gestione dell'azienda asinina. Vol 82. Fondazione Iniziative Zooprofilattiche e Zootrecniche, Brescia, Italy.

Ivanković, A., J. Ramljak, I. Štulina, N. Antunac, I. Bašić, N. Kelava, and M. Konjačić. 2009. Characteristics of the lactation, chemical composition and milk hygiene quality of the Littoral-Dinaric ass. Mljekarstvo 59:107-113.

La Torre, G. L., M. Saitta, A. G. Potortì, G. Di Bella, and G. Dugo. 2010. High performance liquid chromatography coupled with atmospheric pressure chemical ionization mass spectrometry for sensitive determination of bioactive amines in donkey milk. J. Chromatogr. A 1217:5215-5224.

Malacarne, M., F. Martuzzi, A. Summer, and P. Mariani. 2002. Protein and fat composition of mare's milk: Some nutritional remarks with reference to human and cow's milk. Int. Dairy J. 12:869-877.

Mao, X., J. Gu, Y. Sun, S. Xu, X. Zhang, H. Yang, and F. Ren. 2009. Anti-proliferative and anti-tumour effect of active components in donkey milk on A549 human lung cancer cells. Int. Dairy J. 19:703-708

Miranda, G., M. F. Mahé, C. Leroux, and P. Martin. 2004. Proteomic tools to characterize the protein fraction of Equidae milk. Proteomics 4:2496-2509
Monti, G., E. Bertino, M. C. Muratore, A. Coscia, F. Cresi, L. Silvestro, C. Fabris, D. Fortunato, M. G. Giuffrida, and A. Conti. 2007. Efficacy of donkey's milk in treating highly problematic cow's milk allergic children: An in vivo and in vitro study. Pediatr. Allergy Immunol. 18:258-264.

Nazzaro, F., P. Orlando, F. Fratianni, and R. Coppola. 2010. Isolation of components with antimicrobial property from the donkey milk: A preliminary study. Open Food Sci. J. 4:43-47.

Oftedal, O. T., H. F. Hintz, and H. F. Schryver. 1983. Lactation in the horse: Milk composition and intake by foals. J. Nutr. 113:20962106 .

Oftedal, O. T., and R. Jenness. 1988. Interspecies variation in milk composition among horses, zebras, and asses (Perissodactyla: Equidae). J. Dairy Res. 55:57-66.

Orsingher, A. 2011. Latte di asina, elisir di lunga vita per la pelle [Jenny milk, elixir of life for skin]. Pages 227-237 in Latte di asina produzione, caratteristiche e gestione dell'azienda asinina, Vol 82 . Fondazione Iniziative Zooprofilattiche e Zootrecniche, Brescia, Italy.

Piccione, G., F. Fazio, G. Caola, and R. Refinetti. 2008. Daily rhythmicity in nutrient content of asinine milk. Livest. Sci. 116:323327.

Polidori, P., D. Beghelli, P. Mariani, and S. Vincenzetti. 2009. Donkey milk production: State of the art. Ital. J. Anim. Sci. 8:677-683.

Restani, P., C. Ballabio, C. Di Lorenzo, S. Tripodi, and A. Fiocchi 2009. Molecular aspects of milk allergens and their role in clinical events. Anal. Bioanal. Chem. 395:47-56.

Santos, A. S., and A. M. Silvestre. 2008. A study of Lusitano mare lactation curve with Wood's model. J. Dairy Sci. 91:760-766.

SAS Institute. 2001. User's Guide: Statistics. Version 8.01. SAS Institute Inc., Cary, NC.

Simos, Y., A. Metsios, I. Verginadis, A.-G. D'Alessandro, P. Loiudice, E. Jirillo, P. Charalampidis, V. Kouimanis, A. Boulaka, G. Martemucci, and S. Karkabounas. 2011. Antioxidant and anti-platelet properties of milk from goat, donkey and cow: An in vitro, ex vivo and in vivo study. Int. Dairy J. 21:901-906.

Tesse, R., C. Paglialunga, S. Braccio, and L. Armenio. 2009. Adequacy and tolerance to ass's milk in an Italian cohort of children with cow's milk allergy. Ital. J. Pediatr. 35:19.

Vincenzetti, S., P. Polidori, P. Mariani, N. Cammertoni, F. M. Fantuz, and A. Vita. 2008. Donkey's milk protein fractions characterization. Food Chem. 106:640-649.

Zhang, X.-Y., L. Zhao, M.-L. Dong, and F.-Z. Ren. 2008. The antimicrobial activity of donkey milk and its microflora changes during storages. Food Contr. 19:1191-1195. 